\title{
Low-enthalpy Geothermal Energy Potential of Mine Water from Closured Underground Coal Mines in Northern Spain
}

\author{
Javier Menéndez ${ }^{1, *}$ and Jorge Loredo ${ }^{2}$ \\ ${ }^{1}$ HUNASER ENERGÍA, 33005 Oviedo, Spain \\ ${ }^{2}$ UNIVERSITY OF OVIEDO, Mining Exploitation Department, 33004 Oviedo, Spain
}

\begin{abstract}
The contribution of renewable energies to the world's total energy demand has increased particularly during the last decades, and they will continue gaining market share. The European energy and climate policies have as one of their targets $20 \%$ of final energy from renewable origin by 2020 . Underground coal mines closured and flooded constitute large underground reservoirs that can be economically managed to supply geothermal energy (heating and cooling) by means of heat pumps. This paper analyzes the geothermal potential of the water stored inside the coal mines of the Asturian Central Coal Basin (ACCB) and the reduction of $\mathrm{CO}_{2}$ emissions compared to the use of fossil fuels. The results of the study that has been carried out show a capacity of $50 \mathrm{MWt}$. The potential for generation thermal energy is $112,000 \mathrm{MWh} /$ year with an electric consumption of 14,000 MWh/year. The Coefficient Of Performance (COP) medium is $8 \mathrm{kWht} / \mathrm{kWhe}$. The reduction of $\mathrm{CO}_{2}$ emissions compared to other fuel sources can reach $80 \%$.
\end{abstract}

\section{Introduction}

Renewables were the third largest contributor to global electricity production in 2015. They accounted for $22.8 \%$ of world electricity generation, after coal (39.3\%) and gas $(22.9 \%)$ and ahead of nuclear $(10.6 \%)$ and oil $(4.1 \%)$. However, the relative position of renewables and gas can be influenced by various factors among which the weather conditions play prime role. Hydroelectricity supplies the vast majority of renewable electricity, generating $16.0 \%$ of world electricity, which is $70.3 \%$ of total renewable electricity, whilst biofuels and waste, including solid biofuels, play a minor role in electricity generation, supplying $1.9 \%$ of world electricity. Although growing rapidly, geothermal, solar, wind and tide energies accounted for only $4.8 \%$ of world electricity production, $21.2 \%$ of total renewable electricity in 2015 [1].

Geothermal electricity generation remained almost static in the Organisation for Economic Co-operation and Development (OECD) Americas over the period 1990 to 2016, although the region remains the largest geothermal electricity producer, with a $48.8 \%$ share of OECD production in 2016. The United States is the largest producer with $37.2 \%$ of the OECD total in 2016, with a production of $19.2 \mathrm{TWh}$, slightly above the 16.0 TWh level in 1990. The second largest producer is New Zealand, with 7.9 TWh in 2016, representing $15.2 \%$ of total OECD production. Other major producers are Italy (12.0\%), Mexico (11.7\%), and Iceland (9.8\%).

In the framework of a circular economy it can be found new possibilities for mine water which can be considered as a potential resource generating new economic activities in the mining regions.

Another alternative for the use of the closed mines is the construction of Compressed Air Energy Storage (CAES) plants. CAES plants have received increasing research attention lately $[2,3]$. CAES plants uses surplus renewable energy to compress and conventionally store air in underground rock caverns, but it is still a technology under development whereas batteries and other technologies offer smaller capacities. After the closure of the mine, the mining voids resulting from the extractive operations, together with the spaces created due to the fracturing induced by mining, can be filled up with water, once the closured mines are flooded, materializing then a new aquifer or "mining reservoir". Due to the temperature of the stored water, it can be successfully used as a source for low enthalpy geothermal energy. In addition to the production of electrical energy, one of the main uses of the low enthalpy geothermal energy is in the generation of thermal energy.

This paper analyses the geothermal potential of the water stored inside the flooded underground closed mines for heating and cooling of buildings, and the reduction of $\mathrm{CO}_{2}$ emissions compared to conventional fossil fuels, such as natural gas and diesel oil.

\section{Geological and hydrogeological characteristics of the study area}

The Asturian Central Coal Basin (ACCB) is located in north-western Spain, and it constitutes the main coal

\footnotetext{
* Corresponding author: javiermenendezr@gmail.com
} 
mining district of the Iberian Peninsula, with more than two centuries of extractive activity that will be closured for the end of the 2018. Underground mines geometry of this coal basin may be highly complex, with a typical depth of up to $500-600 \mathrm{~m}$, and main infrastructure composed of vertical shafts with a diameter of $6 \mathrm{~m}$, used for mineral extraction and for access of personnel and materials. In the whole of this historical coal mine district has an extensive network of horizontal tunnels at different levels, with an average separation between levels of 80-100 $\mathrm{m}$ [4].

From a geological point of view, the Asturian Central Coal Basin (ACCB) lies within the so-called "Cantabrian Zone", which constitutes the external part of the Variscan Orogen in the NW of Spain. The ACCB can be subdivided into four different geological units (from W to E): Riosa-Olloniego, The Justa- Aramil, Caudal-Nalon and Lois-Ciguera. The whole sedimentary sequence comprises about $6000 \mathrm{~m}$ of Upper Carboniferous siliciclastic-dominating rocks, mainly conglomerates, sandstones, greywackes and mudstones, with a few limestone horizons [5]. From a hydrogeological point of view, the ACCB is constituted by materials of very low porosity and permeability which constitute small aquifers associated to multilayer sandstones, with limestones, shales and coal seams as confining levels. After two centuries of mining activity, the created mine voids and the effect of the induced fracturing on the enclosing rocks have created a secondary permeability which induces important changes into the hydrogeological parameters of the area. A cause of this secondary porosity, the values of porosity, permeability and transmissivity increase significantly from their initial values: porosity from 1 to more than $10 \%$, permeability from $10^{-1}$ to $100 \mathrm{~m} \mathrm{day}^{-1}$, and transmissivity from 10 to $1000 \mathrm{~m}^{2}$ day $^{-1}[6,7]$. From an initial situation before mining, with only small aquifers, the coal mining and the associated fracturing creates a new hydrogeological system. Table 1 shows the results of the mine water analysis that has been performed on two samples in the ACCB.

Table 1. Mine water analysis

\begin{tabular}{lcc}
\hline Parameter & Sample 1 & Sample 2 \\
\hline $\mathrm{T}^{\mathrm{a}}$ Water $\left({ }^{\circ} \mathrm{C}\right)$ & 21,2 & 23 \\
$\mathrm{pH}$ & 7,71 & 7,76 \\
Suspended Solids SS $(\mathrm{mg} / \mathrm{l})$ & $<5,0$ & $<5,0$ \\
Conductivity $(\mu \mathrm{S} / \mathrm{cm}) \mathrm{a} 2^{\circ} \mathrm{C}$ & 1.265 & 1.211 \\
Dissolved Iron $(\mathrm{mg} / \mathrm{l})$ & $<0,050$ & $<0,050$ \\
Iron $(\mathrm{mg} / \mathrm{l})$ & 0,202 & 0,136 \\
Total Iron $(\mathrm{mg} / \mathrm{l})$ & 0,27 & 0,174 \\
Sulphates $(\mathrm{mg} / \mathrm{l})$ & 140 & 70 \\
Carbonates $(\mathrm{mg} / \mathrm{l})$ & $<2,0$ & $<2,0$ \\
Bicarbonates $(\mathrm{mg} / \mathrm{l})$ & 725,3 & 558,9 \\
Dissolved Calcium $(\mathrm{mg} / \mathrm{l})$ & 116 & 54,2 \\
Total Hardness $(\mathrm{mg} \mathrm{CaCO} / \mathrm{l})$ & 5 & 3 \\
Dissolved Potassium $(\mathrm{mg} / \mathrm{l})$ & 11,2 & 8,92 \\
Dissolved Sodium $(\mathrm{mg} / \mathrm{l})$ & 173 & 160 \\
Chlorides $(\mathrm{mg} / \mathrm{l})$ & $<3$ & 11,8 \\
\hline
\end{tabular}

This new "aquifer" behaves similarly to a karst aquifer, with a triple porosity (intergranular pores, fracture spaces, and mining voids for drifts and exploited layers), similar to that of the karst carbonate aquifers [6]. Under these conditions, if the pumping is interrupted, recharge by infiltration causes the flooding of mine voids and creates an underground reservoir, constituted by the mining voids associated to one or more shafts, as they are frequently connected underground [7]. Most of the mining work, whether open or underground, intercepts the piezometric level and forces the establishment of a pumping system, which, if interrupted after the closure of the activity, will bring with it a partial or total flood of the mining tunnels. Presently, the pumping of the infiltrated waters is considered an important cost for the mines, with an average flow of $40 \mathrm{Mm}^{3}$ year-1. Fig. 1 shows the schematic of an underground coal mine of the ACCB.

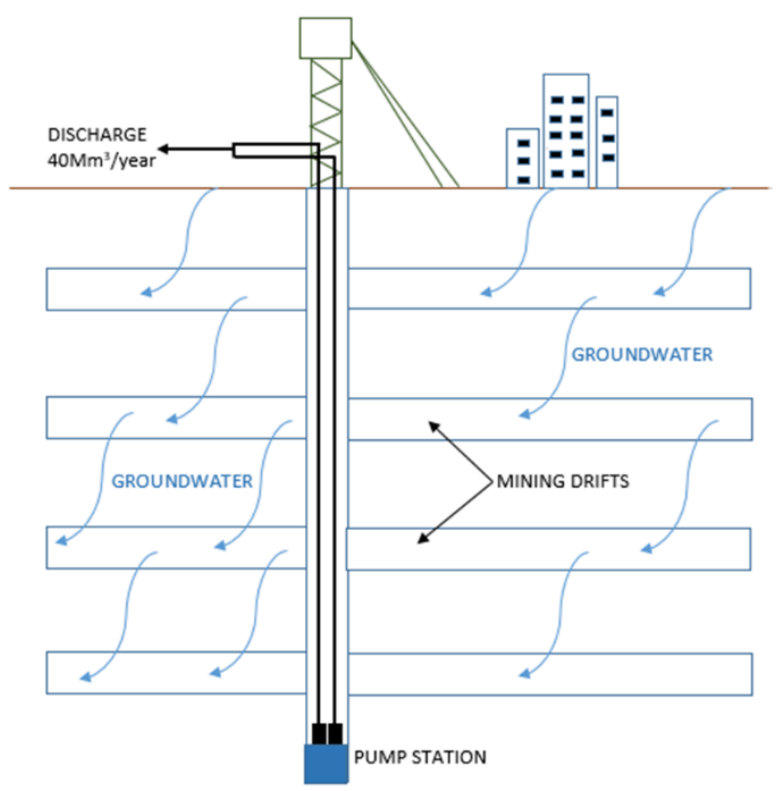

Fig. 1. Groundwater and pump system in production phase.

\section{Analysis of the geothermal potential}

The meteorological data allows calculating the water balance for each one of the mining reservoirs and its associated drainage basin $[8,9]$. Water comes into the system by means of effective rainfall (precipitation minus evapotranspiration) and then divides between runoff and infiltration. The latter can be assimilated to the flow that was as an average pumped from the mining works in the reservoir. The excess of effective rainfall which is not infiltrated into the ground (in the case of the ACCB this part is generally low, due to the reduced permeability) generates runoff that ends into the streams/rivers of the basin [9].

Once pumping is interrupted, leading to the 'groundwater rebound', water level does not rise linearly, as its rise depends on the recharge rate and the volume of voids to fill, being slower when water has to fill mine levels with high volume of voids and quicker between those levels [10]. Considering an average total 
flow of $40 \mathrm{Hm}^{3}$.year-1 pumped in the entire coal mining reservoirs in the ACCB, 1.700 hours year $^{-1}$ for heating [11], the thermal potential of the cool source $(\mathrm{Pc})$ and the warm source $(\mathrm{Pw})$ are, in $\mathrm{W}[12]$ :

$$
\begin{gathered}
P_{C}=\Delta T \cdot F \cdot S H \cdot \rho \\
P_{W}=P_{C} \cdot C O P \cdot(C O P-1)^{-1}
\end{gathered}
$$

where:

$\Delta \mathrm{T}=$ Difference of temperature of mine water going in and out of the evaporator, which is generally $5^{\circ} \mathrm{C}$ for common heat pumps.

$\mathrm{F}=$ Pumped flow $\left(\mathrm{m}^{3} \mathrm{~s}^{-1}\right)$

$\mathrm{SH}=$ Water specific heat $=4,186.8 \mathrm{~J}_{\mathrm{kg}}{ }^{-1}\left({ }^{\circ} \mathrm{C}\right)^{-1}$

$\rho=$ Water density $=1,000 \mathrm{~kg} \mathrm{~m}^{-3}$

$\mathrm{COP}=$ Heat pump coefficient of performance (amount of heat in relation to the drive power required).

Fig. 2 shows the general scheme of a geothermal project using mine water. As indicated in the Figure, the water temperature increases in the deepest areas of the underground reservoir.

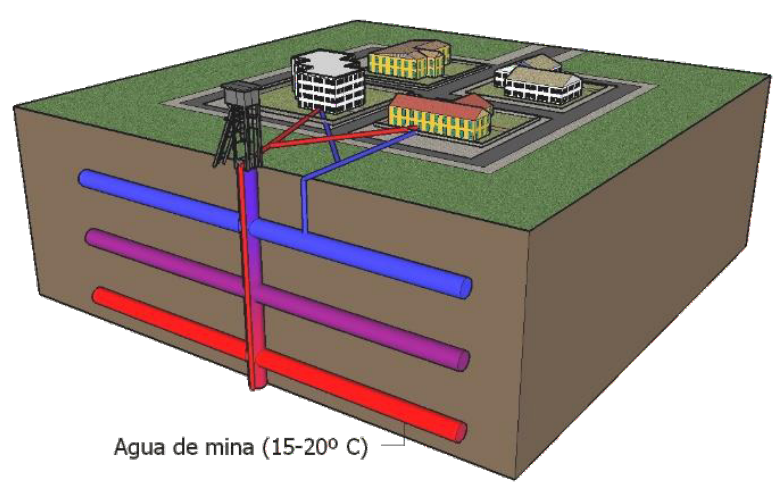

Fig. 2. Geothermal project scheme with mine water

\section{Low-enthalpy geothermal energy production}

\subsection{Energy production}

When the activity in the mines ceases, the pumping works are interrupted and the mining drifts are flooded [13-15]. The average time of inundation of an underground mine in the ACCB is about 4 years. Due to security issues, it is necessary to maintain the water level between $50-100 \mathrm{~m}$ from the surface level, to avoid problems and flooding in nearby populations. The water stored in the coal mines has a geothermal potential equivalent to $50 \mathrm{MWt}$. The production of thermal energy in the existing populations around the closed mines in the form of district heating has been analyzed. Fig. 3 and Fig. 4 show the scheme for the use of mine water as a source of geothermal energy in district heating and cooling projects. The main elements of the facilities are: a tube heat exchanger and the heat pump. To supply thermal energy throughout the year, two modes of operation have been designed. Fig. 3 indicates the heating (winter) mode. In the primary circuit there are temperatures of $22^{\circ} \mathrm{C}$ and $14^{\circ} \mathrm{C}$, and in the secondary circuit of $11^{\circ} \mathrm{C}$ and $14{ }^{\circ} \mathrm{C}$. Fig. 4 indicates the cooling mode (summer). In the primary circuit there are temperatures of $24{ }^{\circ} \mathrm{C}$ and $32{ }^{\circ} \mathrm{C}$, and in the secondary circuit of $28^{\circ} \mathrm{C}$ and $34^{\circ} \mathrm{C}$.

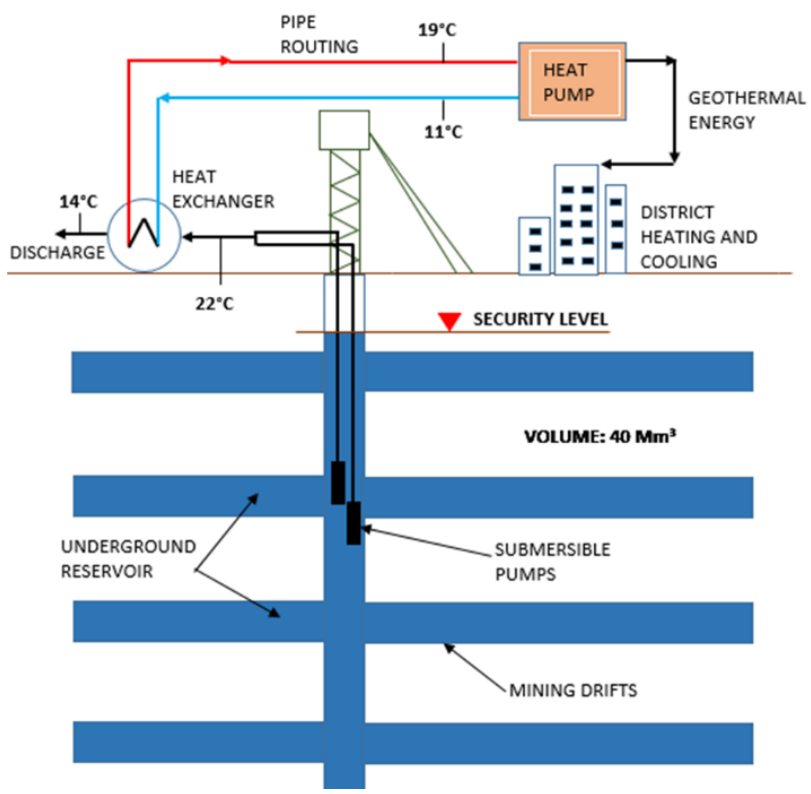

Fig. 3. Geothermal energy production (heating)

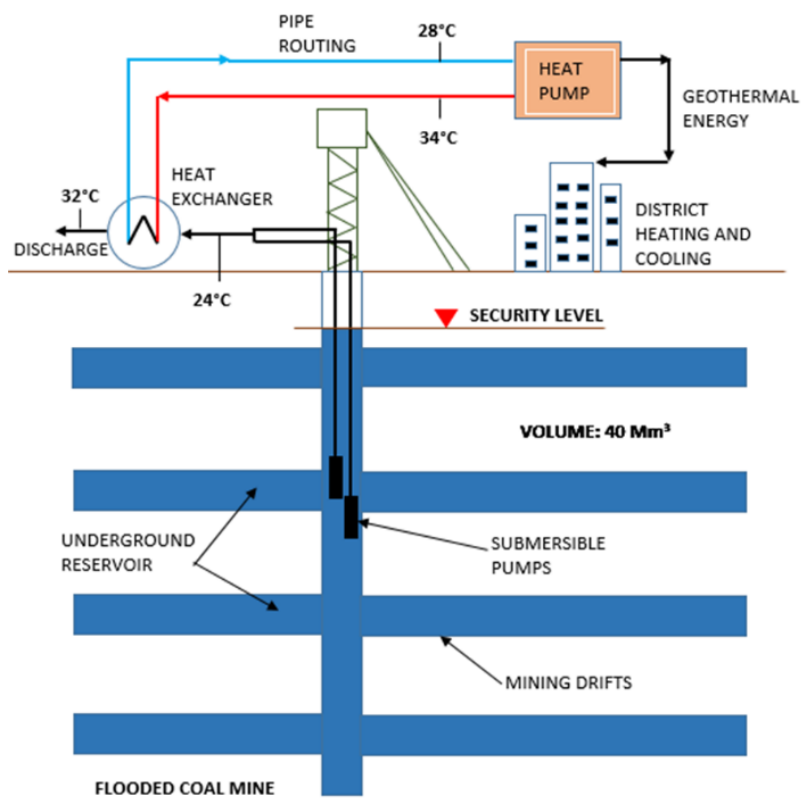

Fig. 4. Geothermal energy production (cooling)

In this study a monthly geothermal energy production model has been made. Depending on the season of the year, the heat pumps can operate in heating mode or cooling mode. The total thermal energy production is $112 \mathrm{GWh} /$ year. The production of energy in heating mode is $76,000 \mathrm{MWh} /$ year and the production in cooling mode is $36,000 \mathrm{kWh} /$ year. Fig. 5 shows the monthly energy production. The electrical consumption in the water recirculation pumps, in the heat pumps and in the submersible pumps located in the vertical well of the underground mine is $14,000 \mathrm{MWh} /$ year. 


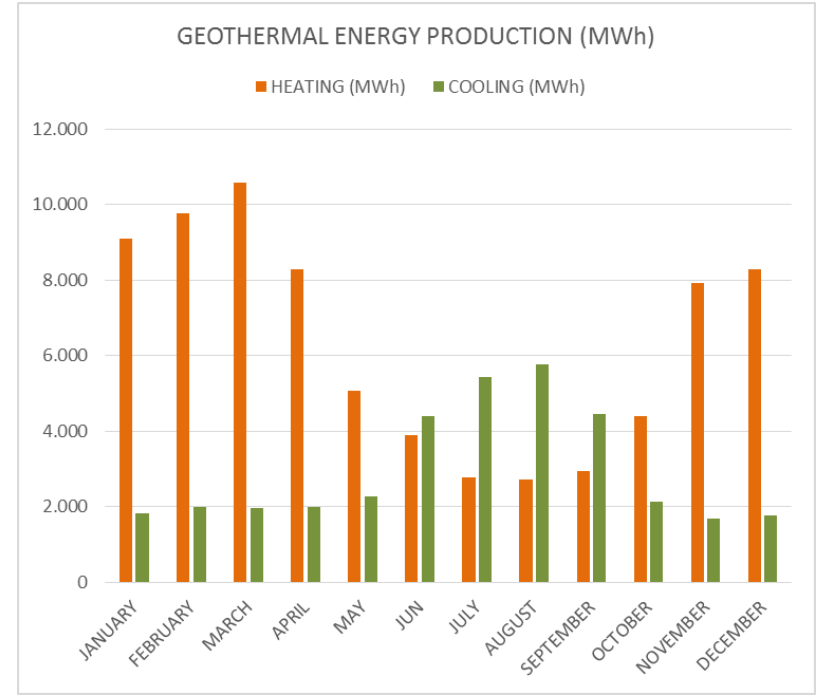

Fig. 5. Geothermal energy production (heating-cooling)

Fig. 6. shows the amount of thermal energy produced and the monthly electrical energy consumed by the heat pump. The result of the Coefficient of Performance $(\mathrm{COP})$ is a value of $8 \mathrm{kWht} / \mathrm{kWhe}$.

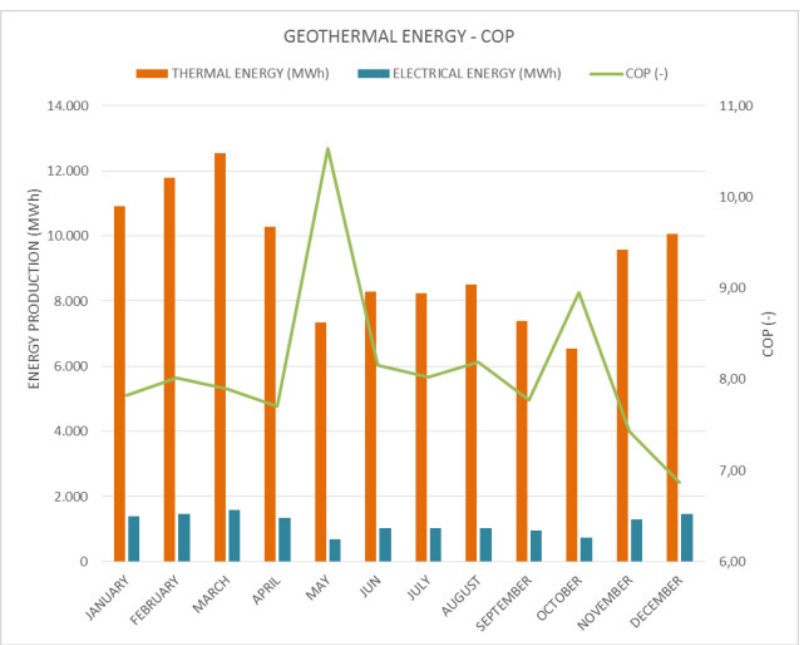

Fig. 6. COP. Geothermal and electrical energy

\section{2. $\mathrm{CO}_{2}$ emissions}

Fig. 7 shows a comparative study of $\mathrm{CO}_{2}$ emissions for fossil fuels and for geothermal energy produced from mine water. For natural gas, considering a factor of $0.204 \mathrm{kgCO}_{2} / \mathrm{kWh}$, emissions of $20 \mathrm{tCO}_{2} /$ year are produced. For diesel, with $0.287 \quad \mathrm{kgCO}_{2} / \mathrm{kWh}$ the emissions reached are $29 \mathrm{tCO} 2 /$ year. The $\mathrm{CO}_{2}$ emissions produced using the mine water are equivalent to the electric power consumption for the heat pump and water pumps, of $5 \mathrm{tCO}_{2} /$ year. The reduction of emissions with respect to diesel can reach $80 \%$.

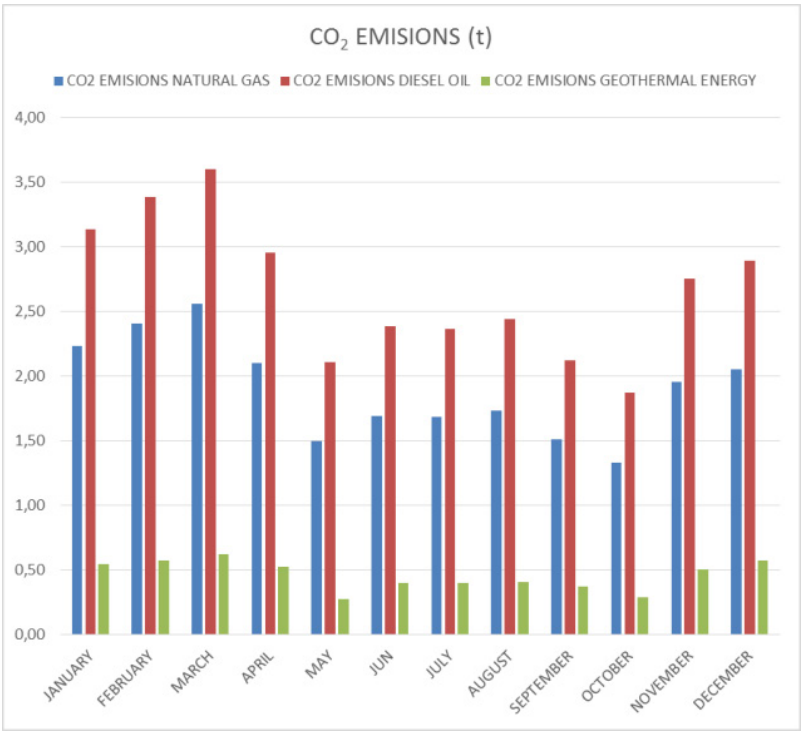

Fig. 7. $\mathrm{CO}_{2}$ emissions. Comparative analysis between fossil fuels and geothermal energy.

\section{Conclusions}

When the activity in the mines ceases, the pumping works are interrupted and the mining drifts are flooded. Closured and flooded coal mines in the ACCB can constitute mining reservoirs which could be regulated and used as water and energy resource. It is essential to define the hydrogeological model, the water balance, and the volume of voids of the mining reservoir system previously to these applications, which fit with an integrated management of water resources, allowing regulating simultaneously both surface and underground resources.

For security reasons, the ACCB mines cannot be completely flooded. It is necessary to leave the water level between $50-100 \mathrm{~m}$ from the surface. This makes it necessary to maintain a system of water pumping permanently that can be used for the production of energy by heat exchangers and heat pump. One of the more attractive applications of mine water is to use it as geothermal resource. The energy use of mine water in the ACCB by means of heat pumps is ideal, due to the high performance that can be reached with an average temperature of $20^{\circ} \mathrm{C}$. The water stored in the closed underground mines in the ACCB has a geothermal potential of about $50 \mathrm{MWt}$ of power. The available energy can supply 40,000 inhabitants in the towns located around the mines. The total thermal energy production is $112 \mathrm{GWh} /$ year. The electrical consumption is about $14,000 \mathrm{MWh} /$ year. In addition, the production of thermal energy from low-enthalpy mine water represents an $80 \%$ reduction in $\mathrm{CO}_{2}$ emissions compared to fossil fuels that are currently being used.

The development of energy production projects in abandoned mines has a positive impact on depressed mining districts due to the closure of coal mines, with the creation of new stable jobs. 


\section{References}

1. International Energy Agency (IEA). Key world energy trends, except from: renewables information.

2. Zhou Y, Xia C, Zhao H, Mei S, Zhou S. An iterative method for evaluating air leakage from unlined compressed air energy storage (CAES) caverns. Renew Energy 2018; 120:434-445.

3. Yang C, Wang T, Li Y, Yang H, Li, J, Qu D, Xu B, Yang Y, Daemen J.J.K. Feasibility analysis of using abandoned salt caverns for large-scale underground energy storage in China. Appl Energy 2015; 137:467-481.

4. Menendez J, Loredo J, Fernandez-Oro J, Galdo M. Underground pumped-storage hydro power plants with mine water in abandoned coal mines. In: Proceedings of the IMWA 13th International Congress, 2017; pp. 6-13.

5. Loredo, J., Ordóñez, A., Jardón, S. Álvarez, R. (2011). Mine water as geotermal resource in Asturian coal mining basins (NW Spain). In: Mine Water - Managing the Challenges. Rude, Freund and Wolkersdorfer Edits., 177-181.

6. García-Fuente, P.A. (1996) Sistema expert de predicción de desagues en minas subterráneas de carbón. Aplicación al Grupo Aller de Hunosa. PhD Thesis, 2 vol. University of Oviedo, Spain.

7. Pendas F, Loredo J (2006) El agua en los procesos de cierre de minas en Asturias. Proceedings of Reunion Cientifico-Tecnica "Gestión del agua en los procesos de cierre de minas". E.T.S. Ingenieros de Minas, Universidad de Oviedo.
8. Jardón S (2010) Aprovechamiento de las aguas de mina en la Cuenca Central Asturiana como recurso energético. Aplicación al embalse minero BarredoFigaredo. PhD Thesis, University of Oviedo.

9. Jardón, S., Ordóñez, A., Álvarez, R., Cienfuegos, P., Loredo, J., 2013. Mine Water for Energy and Water Supply in the Central Coal Basin of Asturias (Spain). Mine Water Environ. 32, 139-151. DOI: 10.1007/s10230-013-0224-X

10. Gandy CJ, Younger, PL (2007) Predicting Groundwater Rebound in the South Yorkshire Coalfield, UK. Mine Water Environ 26: 70-78.

11. Ochsner K (2008) Geothermal Heat Pumps. A guide to Planning \& Installing. Earthscan, London.

12. Bajtos P (2001) Low enthalpy geothermal energy from mine waters in Slovakia. Proceedings of the International Scientific Conference of Geothermal Energy in Underground Mines. Poland.

13. Menendez J, Loredo J, Fernandez-Oro J, Galdo M. Energy storage in underground coal mines in NW Spain: Assessment of an underground lower water reservoir and preliminary energy balance. Renew. Energy 2018; 134:1381-1391.

https://doi.org/10.1016/j.renene.2018.09.042

14. Ordóñez, A., Jardón, S., Álvarez, R., Andrés, C., Pendás, F., 2012. Hydrogeological definition and applicability of abandoned coal mines as water reservoirs. J. Environ. Monit. 14, 2127-2136. DOI: 10.1039/c2em11036a

15. Menendez J, Ordóñez A, Álvarez R, Loredo J. Energy from closed mines: Underground energy storage and geothermal applications. Renew Sustainable Energy Rev 2019;108:498-512. https://doi.org/10.1016/j.rser.2019.04.007 